\title{
APPLICATION OF SULFONATED CARBON CATALYST IN THE HYDROLYSIS REACTION WITH MICROWAVE- ASSISTED
}

\author{
L. Efiyanti ${ }^{1, \bowtie}$, D.A. Indrawan ${ }^{1}$, D. Santi ${ }^{2}$, S. Wibowo ${ }^{1}$ and G. Pari ${ }^{1}$ \\ ${ }^{1}$ Forest Product Research and Development Center, Forestry Research Development and \\ Innovation Center, Ministry of Environment and Forestry, Bogor, Indonesia, 16118. \\ ${ }^{2}$ Department of Chemistry, Faculty of Mathematics and Natural Sciences, University of Papua, \\ Manokwari, Indonesia, 98312. \\ ${ }^{\square}$ Corresponding Author: lisnaefiyanti@gmail.com
}

\begin{abstract}
Wood waste is one of the easily accessible and inexpensive biomass sources that can be further converted into the broadly applicable carbon product, especially as catalysis material. The pyrolysis method at $350^{\circ} \mathrm{C}$ followed by sulfonation under reflux with $\mathrm{H}_{2} \mathrm{SO}_{4} 12 \mathrm{~N}$ was used to obtain a carbon catalyst from wood waste. The sulfonated carbon catalyst (SC) was analyzed based on Indonesian National Standards (SNI 06-3730-1995), consisting of acidity test via ammonia adsorption, identification of functional group using Fourier Transform Infra-Red (FTIR), and crystallinity evaluation using X-ray Diffractometer (XRD). Afterward, the catalytic activity of SC catalyst was examined in the microwave-assisted hydrolysis reaction with varying weight ratios of catalyst to pulp: 1:1; $1: 2 ; 1: 4$; 1:6 and 1:8. In addition, the power condition applied during the catalyzed reaction for 3 and 5 minutes was also varied into 200,400 , and $600 \mathrm{~W}$. The result showed that the most optimum catalytic hydrolysis reaction by carbon catalyst, which generated the highest glucose $(203.98 \mathrm{ppm})$, was carried out using a catalyst to pulp ratio of 1:4 at $600 \mathrm{~W}$ for 5 minutes. From this work, carbon material exhibited great potential to be developed as a green catalyst and, thus, can be expected to substitute the commonly used acid catalysts in the future.
\end{abstract}

Keywords: catalyst, hydrolysis, microwave, pulp, sulfonated carbon

RASĀYAN J. Chem., Vol. 14, No.3, 2021

\section{INTRODUCTION}

Containing convertible cellulose, lignocellulosic material serves as a new source of renewable energy and chemical product availability due to its capability to be converted into glucose and other chemical compounds. ${ }^{1}$ The production of glucose in the conversion of cellulose is especially advantageous as it opens up the possibility to synthesis other valuable chemical compounds, most importantly, ethanol. ${ }^{2}$ One of the highly available lignocellulosic raw materials is wood; comprising lignin, cellulose, pentosan, and carbon source. These materials are considered as a promising alternative source for second-generation bioenergy as well as hydrolysis reaction into fermentable sugar, where it demonstrates no interference towards the food supply chain. ${ }^{3,4}$

One way to convert biomass into glucose is through a microwave-assisted hydrolysis process in the presence of a catalysis material. In previous research, microwave irradiation was used for acid-hydrolysis of sago pith waste. ${ }^{5}$ As energy consumption was evaluated, it was concluded that the microwave-assisted hydrolysis reaction presented a faster and cost-effective approach by saving over $75 \%$ of energy for every $1 \mathrm{~g}$ of glucose obtained. Moreover, microwave irradiation effectively reduces the crystallinity of cellulose and contributes to the improvement of catalyst accessibility that simultaneously leads to an enhanced hydrolysis reaction. ${ }^{6}$

Several types of catalysts that are commonly used in hydrolysis reactions are acid catalysts and enzymes. ${ }^{7,8}$ However, over time, a few drawbacks were found with the use of these catalysts. For instance, the use of enzymes was frequently shown to generate several side products (i.e. HMF, levulinic acid, and formic acid) that are found to inhibit the fermentation process. ${ }^{2}$ In addition to undesired side products, the price of enzymatic procedure that is even higher than the cost of fossil fuels has also made the whole process to be

Rasayan J. Chem., 14(3), 1998-2005(2021)

http://doi.org/10.31788/ RJC.2021.1436276

This work is licensed under a CC BY 4.0 license. 
economically inefficient. ${ }^{4}$ On the other hand, acid catalysts are not favorable due to their phase that is difficult to separate as well as their corrosive and hazardous nature. Collectively, these concerns have prompted the idea to combine $\mathrm{H}_{2} \mathrm{SO}_{4}$ acid and carbon material in developing a sulfonated carbon catalyst that displays an environmentally friendly behavior, included as the solid acid catalyst. The catalyst's easiness to be separated, which depicts its possibility to be reused in multiple hydrolysis processes, becomes the key reason for its low negative impact on the environment to be considered as a feasible catalyst in the biomass conversion into valuable chemical materials. ${ }^{9}$

A high surface area activated carbon that possesses an excellent catalyst characteristic can be prepared from the highly available and low-cost agricultural/forest with carbon content. ${ }^{10}$ Numerous types of acidfunctionalized activated carbon have been successfully used in many hydrolysis reactions, including the use of $\mathrm{H}_{3} \mathrm{PO}_{4}$ /active carbon in the hydrolysis process of sugarcane waste ${ }^{11}$, the use of activated carbon from tea waste for ammonia borane hydrolysis ${ }^{12}$, the use of metal-supported activated carbon for hydrolysis of carbonyl sulfide and carbonyl disulfide ${ }^{13}$, and the use of $\mathrm{H}_{2} \mathrm{SO}_{4} /$ montmorillonite. $^{14}$ According to past researches, employing sulfonated activated carbon prepared with sulfuric acid in the hydrolysis of cellulose for $1.5 \mathrm{~h}$ produced the highest glucose level with over $53.9 \mathrm{wt} \%$ at $180^{\circ} \mathrm{C}$ reaction condition and increased to $85.4 \mathrm{wt} \%$ with the help of a microwave. ${ }^{15,16}$

The study of biomass conversion over a solid acid catalyst or heterogeneous catalyst is a challenging task on its own considering the catalysts themselves should meet several important demands such as high activity, high selectivity, and good stability. This research aims to study the activity of a carbon catalyst in the hydrolysis of lignocellulose. Therefore, it is expected that the carbon-based solid acid catalyst can overcome the disadvantages of past catalysts and created an added value to the forestry and agricultural wastes.

\section{Material and Methods}

\section{EXPERIMENTAL}

In this work, the cellulose source was obtained from Ubar wood (Syzygium sp.). The carbon source was collected from the sawdust of mixed wood waste. Phenol, acetic acid $\left(\mathrm{CH}_{3} \mathrm{COOH}\right)$, potassium sodium tartrate $\left(\mathrm{KNaC}_{4} \mathrm{H}_{4} \mathrm{O}_{6} \cdot 4 \mathrm{H}_{2} \mathrm{O}\right)$, potassium iodide $(\mathrm{KI})$, sodium hypochlorite $(\mathrm{NaClO})$, sulfuric acid $\left(\mathrm{H}_{2} \mathrm{SO}_{4}\right)$, sodium sulfate $\left(\mathrm{Na}_{2} \mathrm{SO}_{4}\right)$, sodium hydroxide $(\mathrm{NaOH})$, alcohol, hydrochloric acid $(\mathrm{HCl})$, and ammonia were all purchased from Merck-Germany. Dinitrosalicylic acid (DNS) was obtained from Sigma Aldrich. Benzene was provided by Smart Lab-Indonesia.

\section{Preparation of Sulfonated Carbon Catalyst (SC)}

The carbon catalyst was obtained by pyrolyzing wood waste sawdust at $350^{\circ} \mathrm{C}$ for $4 \mathrm{~h}$ (noted as $\mathrm{C}$ ). Afterward, the product was filtered and sulfonated using $\mathrm{H}_{2} \mathrm{SO}_{4} 12 \mathrm{~N}$ at $150^{\circ} \mathrm{C}$ for $4 \mathrm{~h}$ under reflux condition. ${ }^{17}$ The sulfonated product was then washed to neutral $\mathrm{pH}$ and dried at $105^{\circ} \mathrm{C}$ prior to its calcination at $500^{\circ} \mathrm{C}$ for $1 \mathrm{~h}$ (noted as SC). ${ }^{18}$

\section{Characterization of SC}

Based on Indonesian National Standards (SNI 06-3730-1995) (Badan Standardisasi Nasional, 1995), the carbon catalyst was evaluated to understand the quality of activated carbon. In this study, the functional groups constructing the activated carbon were identified using Fourier Transform Infrared (FTIR-BRUKER Tensor37). The crystallinity of the catalyst was observed using X-Ray Diffraction (XRD-7000 ShimadzuJapan) operated with $\mathrm{Cu}$ Ka radiation scanned at 40kV within 10-80 degrees using 0.6 second pre-set time. Furthermore, the acidity of the carbon catalyst was analyzed through the gravimetrical method using ammonia as adsorbate. The adsorption method of ammonia is explained below. One gram of carbon sample was put into an evaporating dish, placed into a desiccator that was previously saturated with ammonia vapor, and allowed to stand for 24 hours.

Ammonia adsorption $(\mathrm{mmol} / \mathrm{g})=\left[\frac{W 3-W 2}{W 2-W 1} M\right] \times 1000$

Remarks:

W1: the weight of the empty evaporating disk

W2: the weight of evaporating dish + sample before treatment 
W3: the weight of evaporating dish + sample after treatment

M: molecular weight of ammonia $\left(\mathrm{g} \cdot \mathrm{mol}^{-1}\right)$

\section{Production of Ubar Wood Pulp}

The Ubar wood was processed into pulp through a crafting process using rotary digester, $\mathrm{NaOH}$, and $\mathrm{Na}_{2} \mathrm{~S}$ as a chemical reagent. Its chemical components were then analyzed and referred to SNI (Indonesian National Standards) 8400:2017 (Badan Standardisasi Nasional, 2017), 0492:2008 (Badan Standardisasi Nasional, 2008), and 01-1561-1989 (Badan Standardisasi Nasional, 1989).

\section{Activity of Carbon Catalyst in Ubar Hydrolysis Reaction}

The carbon catalyst was employed in the hydrolysis reaction of pulp assisted by a microwave set at 200, 400, and 600 Watt for 3 and 5 minutes. The weight ratios of catalyst to a pulp were varied into $1: 1 ; 1: 2$; $1: 4 ; 1: 6$ and 1:8 (wt/wt) using water as reaction medium. This activity test was conducted with two times replication. The hydrolysate product was analyzed using UV-Vis (UV-1700 Shimadzu) by the DNS method. ${ }^{19}$ Aside from analyzing hydrolysis filtrate, the analysis of glucose concentration following the glucose standard curve equation was also carried out.

\section{RESULTS AND DISCUSSION}

\section{Characteristics of Carbon (C) and Sulfonated Carbon Catalyst (SC)}

Table-1 presented the carbon analysis data in comparison to the requirement set by SNI 06-3730-1995, which includes recovery value, moisture, volatile matter, ash content, and fixed carbon content. The recovery value of SC catalyst is about $65.08 \pm 0.31 \%$ due to the detachment of carbon from the washing process. The moisture, volatile matter, ash content, and fixed carbon of $\mathrm{C}$ and $\mathrm{SC}$ were shown to comply with SNI standards.

Table-1: The Characterization Analysis of Synthesized Materials based on Indonesian National Standard 06-37301995

\begin{tabular}{c|c|c|c|c|c|c|c}
\hline \multirow{3}{*}{ Sample } & \multicolumn{7}{c}{ Characterization Analysis } \\
\cline { 2 - 8 } & $\begin{array}{c}\text { Recovery } \\
\text { Value } \\
(\%)\end{array}$ & $\begin{array}{c}\text { Moisture } \\
\text { Content } \\
(\%)\end{array}$ & $\begin{array}{c}\text { Volatile } \\
\text { Matter } \\
(\%)\end{array}$ & $\begin{array}{c}\text { Ash } \\
\text { Content } \\
(\%)\end{array}$ & $\begin{array}{c}\text { Fixed } \\
\text { Carbon } \\
(\%)\end{array}$ & $\begin{array}{c}\text { Iodine } \\
\text { Adsorption } \\
(\mathrm{mg} / \mathrm{g})\end{array}$ & $\begin{array}{c}\text { Ammonia } \\
\text { Adsorption } \\
(\mathrm{mmol} / \mathrm{g})\end{array}$ \\
\hline $\mathrm{C}$ & $34.00 \pm 0.26$ & $1.84 \pm 0.16$ & $12.02 \pm 0.12$ & $5.81 \pm 0.16$ & $82.09 \pm 0.15$ & $216.96 \pm 0.18$ & $4.28 \pm 0.09$ \\
\hline SC & $65.08 \pm 0.31$ & $4.35 \pm 0.65$ & $6.09 \pm 0.06$ & $9.51 \pm 0.04$ & $84.40 \pm 0.57$ & $478.51 \pm 0.69$ & $5.61 \pm 0.28$ \\
\hline SNI & & $<15$ & $<25$ & $<10$ & $>65$ & $>750$ & \\
\hline
\end{tabular}

The high temperature applied during the carbonization and activation process decreases the stability of organic molecules and eventually leads to the splitting of intermolecular bonds. Therefore, as contaminants were subsequently removed and volatile matters were released into gas and liquid products, fixed carbon can simultaneously increase. ${ }^{20}$ The rise of ammonia adsorption that is seen after the sulfonation of carbon indicates the opening pores and catalyst active site (Table-1). The adsorption illustrates the acidity strength of the carbon catalyst, which correlates linearly to the amount of active site in the catalyst and, hence, its catalytic activity. ${ }^{21-23}$

Although iodine adsorption of SC $(478.51 \pm 0.69 \mathrm{mg} / \mathrm{g})$ still appeared below the established requirement, which may have been due to adsorption interference from several components on the surface of the catalyst, activation with sulfuric acid had greatly improved this character to approximately twice from the initial value. The occurrence can be linked to the removal of contaminants and pore opening of carbon material induced by the addition of sulfuric acid, allowing the catalyst to adsorb more iodine as opposed to nonsulfonated carbon (C). On the other hand, Table-2 showed several different FTIR spectra presented by C and $\mathrm{SC}$ catalysts. The success of the activation process can be indicated from four main functional groups: $\mathrm{OH}, \mathrm{CO}, \mathrm{C}=\mathrm{C}$, and $\mathrm{O}=\mathrm{S}$. It was revealed that the vibration band of the $-\mathrm{OH}$ group appeared at wavenumber 3399 and $3397 \mathrm{~cm}^{-1}$ for C and SC catalysts, respectively. However, in contrast to the C catalyst, SC was 
RASĀYAN J. Chem.

Vol. 14 | No. 3 |1998-2005| July - September | 2021

seen to display $\mathrm{CO}$ and $\mathrm{S}=\mathrm{O}$ vibration bands at a wavenumber of 1795 and $1207 \mathrm{~cm}^{-1}$, respectively. According to the literature, the formation of the sulfonic group can be observed from the vibration band of $\mathrm{S}-\mathrm{O}$ and $\mathrm{SO}_{3}$ commonly indicated at a wavenumber of 1037,1040 , and $1200 \mathrm{~cm}^{-1}$ or 1372 and $1025 \mathrm{~cm}^{-1}$. ${ }^{15}$ Shen et al. ${ }^{24}$ reported that the vibrations around 1209 and $1030 \mathrm{~cm}^{-1}$ correspond to the presence of $\mathrm{S}=\mathrm{O}$ from $-\mathrm{SO}_{3} \mathrm{H}$ while the presence of $\mathrm{O}-\mathrm{H}, \mathrm{C}=\mathrm{O}$, and $\mathrm{C}=\mathrm{C}$ can respectively be detected at wavenumber 3300 , 1666 , and $1605 \mathrm{~cm}^{-1}$. Furthermore, the carboxylic acid group can also be confirmed in the appearance of the vibration band at $1750 \mathrm{~cm}^{-1} .25$

Table-2: The FTIR Data of Carbon and Sulfonated Carbon Catalyst

\begin{tabular}{c|c|c|c|c|c}
\hline \multirow{2}{*}{ Sample } & \multicolumn{5}{|c}{ Wavenumber $\left(\mathrm{cm}^{-1}\right)$} \\
\cline { 2 - 6 } & $\mathrm{OH}$ & $\mathrm{CO}$ & $\mathrm{C}=\mathrm{C}$ & $\mathrm{O}=\mathrm{S}$ & $\mathrm{C}-\mathrm{H}$ \\
\hline $\mathrm{C}$ & 3399 & & 1608 & & - \\
\hline $\mathrm{SC}$ & 3397 & 1795 & 1594 & 1207 & 857 \\
\hline
\end{tabular}

Figure-1 describes the diffractogram data of $\mathrm{C}$ and $\mathrm{SC}$ samples using XRD. As expected, the pattern of samples with and without sulfonate groups showed differences. In Fig.-1a, the diffractogram of $\mathrm{C}$ samples (Fig.-1c) was compared to the structure of cubic carbon- $\mathrm{C}_{60}$ crystal according to JCPDS references (PDF card no. 044-0558). The pattern of $\mathrm{C}$ samples confirmed that the carbon was formed by mainly amorphous carbon with a peak at $20.78^{\circ}\left(\mathrm{d}_{\mathrm{hkl}}=311\right)$. However, the broad peak of $(002)$ crystal plane graphite layer centered at $2 \theta=23^{\circ}$ cannot be significantly detected in the diffractogram of $\mathrm{C}$ catalyst. The result indicates that carbonization at $350{ }^{\circ} \mathrm{C}$ is not capable of completely transforming the raw material structure into the typical turbostratic carbon structure. Generally, carbon derived from biomass displays two broad peaks centered on $2 \theta=23^{\circ}$ and $43^{\circ}$, representing the structure of a crystalline plane (002) and (100) from the graphite layer with random orientation, as discussed in the previous findings. ${ }^{26-28}$

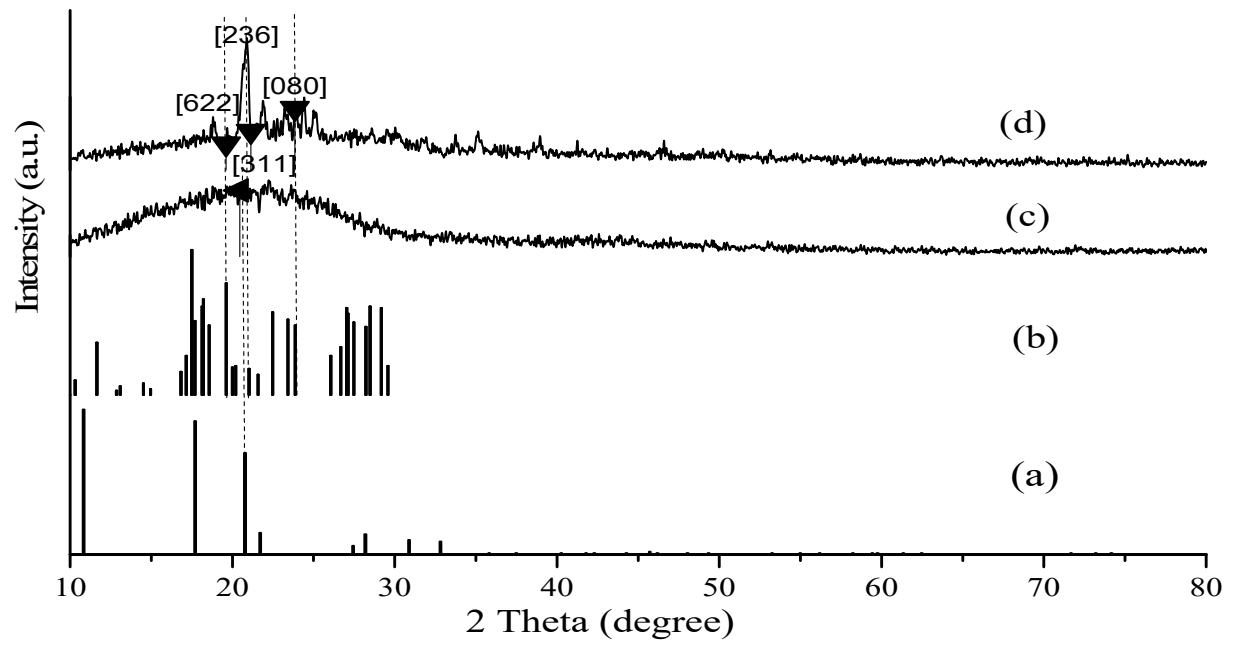

Fig.-1: XRD Pattern of (a) JCPDS no. 044-0558, (b) JCPDS no. 052-0976, (c) C, and (d) SC Sample

On the other hand, SC catalyst (Fig.-1d) showed peaks at $19.68^{\circ}, 21.56^{\circ}$, and $23.42^{\circ}$, corresponding to the crystal plane of orthorhombic carbon sulfide- $\mathrm{C}_{70} \mathrm{~S}_{8}$ with $\mathrm{d}_{\mathrm{hkl}}=(622),(236)$, and (080), respectively (JCPDS no. 052-0976). This pattern indicating that the sulfur component binds with carbon structure in amorphous and crystalline phases. The pattern of SC was similar to the carbon catalyst reported by Cheng et al. ${ }^{29}$ The crystallinity of C and SC was $7.54 \%$ and $26.85 \%$, respectively. The increase in crystallinity highlighted that sulfonation and calcination processes have successfully produced a more ordered carbon structure.

\section{Chemical Component of Ubar Wood Pulp}

The pulp is attractive to be developed as a raw material for glucose conversion because it is easier to be further transformed into several other products, such as bioethanol, alcohols, methyl ester, and many more. The direct conversion of pulp into glucose consists of a simple and effective process from an economical point of view. ${ }^{30}$ In general, the pulp from biomass is composed of cellulose, hemicellulose, and lignin, with 
cellulose as the dominant compound. Cellulose is a polymer from the glucose unit which is connected by the 1,4 glycosidic bonding to form a neatly organized microfibril structure. Hemicellulose is a branched polysaccharide comprising xylose and arabinose. Meanwhile, lignin is a complex polymer containing pcoumaryl, conyferyl, and sinapyl alcohol that protect the plant cell and are responsible for the hardlydecomposed structure of lignocellulose.$^{31}$ In addition to strength and rigidity, lignin also protects plant cells against degradation. ${ }^{32}$ Glucose can be obtained from the hydrolysis of cellulose that also produces several other chemicals such as bioethanol, dimethylfurane, hydroxymethylfurfural, and levulinic acid. ${ }^{33-35}$ For this reason, in this study, it is important for Ubar wood to be pre-treated in the pulp-producing process to reduce its lignin content while simultaneously increasing the cellulose composition. This way, the feed material would be easier to be degraded and hydrolyzed to produce glucose.

Table-3: The Chemical Components of Ubar Wood Pulp

\begin{tabular}{c|c|c|c}
\hline \multirow{2}{*}{ Sample } & \multicolumn{3}{|c}{ Chemical Components (\%) } \\
\cline { 2 - 4 } & Cellulose & Lignin & Pentosan \\
\hline $\begin{array}{c}\text { Ubar Wood } \\
\text { Pulp }\end{array}$ & 80.40 & 2.78 & 17.65 \\
\hline
\end{tabular}

During the pulp-producing process, Ubar wood was treated using alkali $(\mathrm{NaOH})$. The addition of alkali will remove lignin or hemicellulose compound from the biomass so that the conversion of cellulose by the catalyst can be maximized. ${ }^{36}$ According to Table-3, it can be seen that cellulose became the major component of Ubar wood pulp, followed respectively by pentosan and lignin. The higher the cellulose content is, the higher the glucose yield that can be expected from the hydrolysis reaction. This result was in agreement with Rai et al. ${ }^{37}$ where, in comparison to acid addition and no treatment, an alkaline pretreatment exhibited an increase of substrate ability in creating more glucose. Moreover, Kang et al. ${ }^{38}$ reported that the key factors affecting the biomass hydrolysis process were the biomass composition, biomass surface access, catalyst, and the biomass preliminary treatment process. Lignin removal is important to enhance the hydrolysis rate and glucose content, particularly from biomass. ${ }^{39,40}$

\section{Microwave-assisted Hydrolysis of Ubar Pulp using SC Catalyst}

The activity test was conducted to understand the potential of carbon material to be used as a catalyst in the microwave-assisted hydrolysis of Ubar pulp. According to Fig.-2, the glucose products are ranged from $139 \mathrm{ppm}-203 \mathrm{ppm}$. The maximum glucose content was obtained during a 5-minute hydrolysis reaction using a catalyst to pulp ratio of 1:4 (wt:wt) with $600 \mathrm{~W}$. From the result, it was shown that the rise in the applied power, time response, and source of cellulose tend to increase the glucose content. In a short reaction time, the contact between the reactants and the catalyst is not optimal. A sufficient reaction time is needed to allow reactant adsorption, collisions between reactants, the interaction between reactant and catalyst, as well as chain degradation of cellulose into glucose. The elongation of reaction time increased the glucose yield, as consistent with the work of Hermiati et al. ${ }^{41}$

The higher the power usage, the contact between reactants and catalysts is expected to be more frequent. However, a slight decrease of glucose was found in the use of 1:6 and 1:8 catalyst to pulp (wt:wt) ratio in the 5-minute reaction. This is most likely due to a possible secondary reaction that releases other side products such as levulinic acid or HMF during glucose production. The presence of glucose in the hydrolysis product was related to the splitting of 1,4-glycosidic bonds in the structure of cellulose, whereas the formation of other side products such as HMF is linked to the dehydration that caused glucose partial decomposition. On the other hand, a greater amount of pulp employed in the hydrolysis reaction will naturally produce a higher glucose compound as it serves as a reactant and a source of cellulose (Fig.-2).

The yield of glucose in this research is still lower than the product obtained from biomass using an enzymatic hydrolysis process in a batch reactor that generated $130{\mathrm{~g} . \mathrm{L}^{-1}}^{\text {glucose concentration. }}{ }^{7}$ This is possibly caused by the differences in reaction conditions and equipment. The acidity and $\mathrm{SO}_{3} \mathrm{H}$ group affect the catalyst activity as well as the product of the hydrolysis reaction. ${ }^{42}$ The presence of functional groups such as $\mathrm{OH}$ and $\mathrm{COOH}$ facilitated interaction with the cellulose chain, thus, drawing the feed compound closer to the active center of $\mathrm{SO}_{3} \mathrm{H}$ where the cleavage of the $\beta$-glycosidic bond occurred in the hydrolysis 
RASĀYAN J. Chem.

Vol. 14 | No. 3 |1998-2005| July - September | 2021

process. ${ }^{43}$ These findings are in agreement with the result obtained from FTIR in which OH species facilitated the hydrolysis of carbonyl sulfide and carbonyl disulfide. ${ }^{13}$

The hydrolysis activity was not only affected by feed sequestration, but also by the collision with the $\mathrm{SO}_{3} \mathrm{H}$ functional group and adsorption capacity. ${ }^{25}$ Based on this data, it is noticed that the activated carbon plays an important role as a catalyst in the hydrolysis of Ubar pulp. Activated carbon can be used as a catalyst support or as a stand-alone catalyst that mediates hydrolysis reaction. ${ }^{44}$ In confirming this fact, the product of hydrolysis reaction carried out in the presence of $\mathrm{H}_{2} \mathrm{SO}_{4} 12 \mathrm{~N}$, non-sulfonated carbon and water was carefully compared (Table-4).

a)

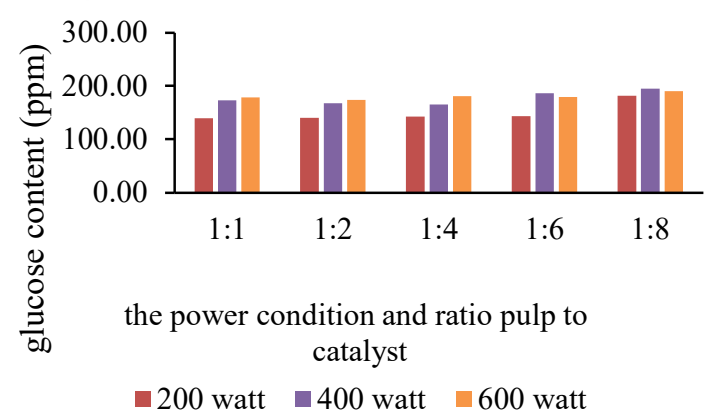

b)

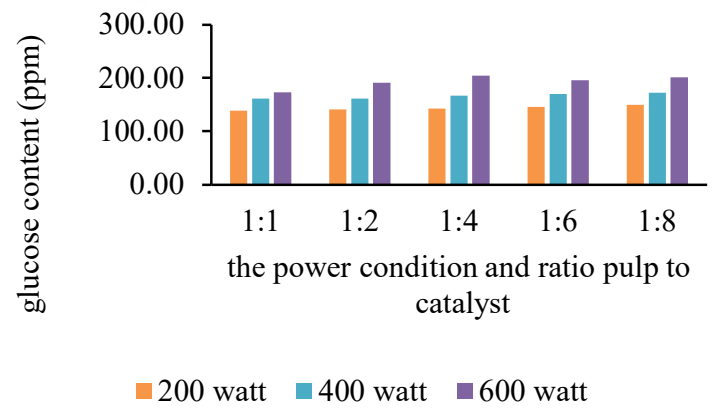

Fig.-2: Ubar Pulp Hydrolysis Data using Carbon Catalyst in 3 (a) and 5 (b) minutes Reaction

Table-4: The Glucose Content in the Ubar Pulp Hydrolysis Reaction without Carbon Catalyst

\begin{tabular}{c|c}
\hline Reaction Conditions & Glucose $(\mathrm{ppm})$ \\
\hline $\mathrm{H}_{2} \mathrm{SO}_{4} 12 \mathrm{~N}$ & 174.62 \\
\hline Carbon $(\mathrm{C})$ & 113.06 \\
\hline Water & 112.48 \\
\hline
\end{tabular}

However, the use of $\mathrm{H}_{2} \mathrm{SO}_{4}$ allegedly showed a low catalytic activity due to the occurrence of hydration. As opposed to the easily hydrated sulfuric acid, which subsequently decreases its acidity, the $\mathrm{SO}_{3} \mathrm{H}$ functional group grafted on the surface of carbon catalyst is more stable and thus, able to perform a better catalytic activity. ${ }^{45}$ This result is consistent with a previous study that showed an increase in glucose yield in the microwave-assisted hydrolysis process using activated carbon. ${ }^{46}$ The presence of activated carbon enhanced the activity of hydrolytic enzyme genes and was able to maintain its superiority characters in stimulating hydrolysis as reported by Yan et al. ${ }^{47}$ The catalysis reaction with microwave-assisted can be promising methods for further development. ${ }^{48}$

\section{CONCLUSION}

In summary, the highest glucose content, with over $203.98 \mathrm{ppm}$, can be obtained in the 5-minute microwave-assisted hydrolysis of Ubar pulp using carbon with the catalyst to pulp weight ratio of 1:4 (wt:wt) and power usage of 600 Watt. This catalyst was made from wood waste and had the potential to be developed into a renewable green catalyst that is selective, high performing, and more environmentally friendly.

\section{ACKNOWLEDGEMENT}

We would like to thank all of the technicians in the Chemistry Integrated laboratory in the Forest Products Research and Development Centre for helping us with this work.

\section{REFERENCES}

1. I. B. W. Gunam, Y. Setiyo, N. S. Antara, I. M. M. Wijaya, I. W. Arnata, I. W. W. P. Putra, Rasayan Journal of Chemistry, 13, 1022(2020), https://doi.org/10.31788/RJC.2020.132557

2. T. M. Lacerda, M. D. Zambon, E. Frollini, Industrial Crops and Products, 71, 163(2015), https://doi.org/10.1016/j.indcrop.2015.03.072

3. C. V. Abiaziem, A. B. Williams, A. I. Inegbenebor, C. T. Onwordi, C. O. Ehi-Eromosele, L. F. Petrik, 
RASĀYAN J. Chem.

Vol. 14 | No. 3 |1998-2005| July - September | 2021

Rasayan Journal of Chemistry, 13, 177(2020), https://doi.org/10.31788/RJC.2020.1315328

4. W. D. H. Schneidera, T. A. Gonçalvesc, C. A. Uchimab, L. dos Reisa, R. C. Fontanaa, F. M. Squinac, A. J. P. Dillona, M. C. Schneider, Process Biochemistry, 66, 162(2018), https://doi.org/10.1016/j.procbio.2017.11.004

5. S. K. Thangavelu, T. Rajkumar, D. K. Pandi, A. S. Ahmed, F. N. Ani, Waste Management, 86, 80(2019), https://doi.org/10.1016/j.wasman.2019.01.035

6. C. Veluchamy, A. S. Kalamdhad, Journal of Cleaner Production, 168, 219(2017), https://doi.org/10.1016/i.jclepro.2017.09.040

7. J. U. Hernández-Beltrán, H. Hernández-Escoto, Biomass and Bioenergy, 119, 191(2018), https://doi.org/10.1016/i.biombioe.2018.09.020

8. X. Yua, X. Baoa, C. Zhoua, L. Zhanga, A. E. A. Yagoubb, H. Yanga, H. Ma, Ultrasonics Sonochemistry, 41, 410(2018), https://doi.org/10.1016/j.ultsonch.2017.09.003

9. M. Marzo, A. Gervasini, P. Carniti, Carbohydrate Research, 347, 23(2012), https://doi.org/10.1016/j.carres.2011.10.018

10. Z. D. Herdea, R. Dharmasenaa, G. Sumanasekeraa, J. S. Tumulurub, J. Satyavolu, Carbon Resources Conversion, 3, 19(2020), https://doi.org/10.1016/j.crcon.2019.12.002

11. N. Suriyachai, V. Champreda, C. Sakdaronnarong, A. Shotipruk, N. Laosiripojana, Renewable Energy, 113, 1141(2017), https://doi.org/10.1016/j.renene.2017.06.003

12. S. Akbayrak, Z. Özçifçi, A, Tabak, Biomass and Bioenergy, 138, (2020), https://doi.org/10.1016/j.biombioe.2020.105589

13. K. Li, C. Wang, P. Ning, K. Li, X. Sun, X. Song, Y. Mei, Journal of Environmental Sciences (China), 96, 44(2020), https://doi.org/10.1016/j.jes.2020.03.019

14. D. S. Tong, X. Xia, X. P. Luo, L. M. Wu, C. X. Lin, W. H. Yu, C. H. Zhou, Z. K. Zhong, Applied Clay Science, 74, 147(2013), https://doi.org/10.1016/j.clay.2012.09.002

15. H. T. Vo, V. T. Widyaya, J. Jae, H. S. Kim, H. Lee, Bioresource Technology, 167, 484(2014), https://doi.org/10.1016/j.biortech.2014.06.025

16. X. Xiong, I. K. M. Yu, S. S. Chen, D. C. W. Tsang, L. Cao, H. Song, E. E. Kwon, Y. S. Ok, S. Zhang, C. S. Poon, Catalysis Today, 314, 52(2018), https://doi.org/10.1016/j.cattod.2018.02.034

17. S. Li, Z. Gu, B. E. Bjornson, A. Muthukumarappan, Journal of Environmental Chemical Engineering, 1, 1174(2013), https://doi.org/10.1016/j.jece.2013.09.004

18. A. C. Fraga, C. P. B. Quitete, V. L. Ximenes, E. F. Sousa-Aguiar, I. M. Fonseca, A. M. B. Rego, Journal of Molecular Catalysis A: Chemical, 422, 248(2016), https://doi.org/10.1016/j.molcata.2015.12.005

19. G. L. Miller, Analytical Chemistry, 31, 426(1959), https://doi.org/10.1021/ac60147a030

20. M. A. Ahmad, N. A. A. Puad, O. S. Bello, Water Resources and Industry, 6, 18(2014), https://doi.org/10.1016/j.wri.2014.06.002

21. F. Rahmawati, S. Wahyuni, S. Kadarwati, Indonesian Journal of Chemical Science, 1,20(2012)

22. F. Xie, P. Jonathan, I. F. Silva, M. C. Palma, J.A. Menéndez, Carbon, 38, 691(2000), https://doi.org/10.1016/S0008-6223(99)00156-6

23. W. Trisunaryanti, Triyono, S. Anjarsari, Jurnal Sains MIPA, 14, 150(2008)

24. S. Shen, C. Wang, B. Cai, H. Li, Y. Han, T. Wang, H. Qin, Fuel, 113, 644(2013), https://doi.org/10.1016/j.fuel.2013.06.021

25. X. Peng, S. Shen, C. Wang, T. Li, Y. Li, S. Yuan, X. Wen, Molecular Catalysis, 442, 133(2017), https://doi.org/10.1016/j.mcat.2017.09.012

26. E. Altintig, S. Kirkil, Journal of the Taiwan Institute of Chemical Engineers, 63, 180(2016), https://doi.org/10.1016/j.jtice.2016.02.032

27. P. C. Bhomick, A. S. R. Karmaker, M. Baruah, C. Pongener, D. Sinha, Korean Journal of Chemical Engineering, 36, 551(2019), https://doi.org/10.1007/s11814-019-0234-x

28. D. Santi, Triyono, W. Trisunaryanti, I. I. Falah, Journal of Environmental Chemical Engineering, 8, 103735(2020), https://doi.org/10.1016/j.jece.2020.103735

29. Y. Cheng, S. Ji, Y. Liu, J. Liu, Arabian Journal of Chemistry, 12, 3517(2019), https://doi.org/10.1016/j.arabjc.2015.10.001

30. J. E. Naicker, R. Govinden, P. Lekha, B. Sithole, Journal of Environmental Management, 270, 
RASĀYAN J. Chem.

Vol. 14 | No. 3 |1998-2005| July - September | 2021

110914(2020), https://doi.org/10.1016/j.jenvman.2020.110914

31. K. Weerasai, V. Champreda, C. Sakdaronnarong, A. Shotipruk, N. Laosiripojana, Food and Bioproducts Processing, 110, 136(2018), https://doi.org/10.1016/j.fbp.2018.05.005

32. I. Haq, P. Mazumder, A. S. Kalamdhad, Bioresource Technology, 312, 123636(2020), https://doi.org/10.1016/j.biortech.2020.123636

33. A. Limayem, S. C. Ricke, Progress in Energy and Combustion Science, 38, 449(2012), https://doi.org/10.1016/j.pecs.2012.03.002

34. Z. Yang, H. Kang, Y. Guo, G. Zhuang, Z. Bai, H. Zhang, C. Feng, Y. Dong, Industrial Crops and Products, 46, 205(2013), https://doi.org/10.1016/j.indcrop.2013.01.031

35. Ni. I. Villanueva, T. G. Marzialetti, Catalysis Today, 302, 100(2018), https://doi.org/10.1016/j.cattod.2017.04.049

36. Y. Gao, J. Xu, Z. Yuan, Y. Zhang, Y. Liu, C. Liang, Bioresource Technology, 167, 41(2014), https://doi.org/10.1016/j.biortech.2014.05.034

37. R. Rai, M. Bibra, B. S. Chadha, R. K. Sani, International Journal of Biological Macromolecules, 137, 232(2019), https://doi.org/10.1016/j.ijbiomac.2019.06.221

38. S. Kang, J. Fu, G. Zhang, Renewable and Sustainable Energy Reviews, 94, 340(2018), https://doi.org/10.1016/j.rser.2018.06.016

39. B. Song, F. Buendia-Kandia, Y. Yu, A. Dufour, H. Wu, Bioresource Technology, 288, 121522(2019), https://doi.org/10.1016/j.biortech.2019.121522

40. Q. Wang, M. S. Jahan, S. Liu, Q. Miao, Y. Ni, Bioresource Technology. 164, 380(2014), https://doi.org/10.1016/j.biortech.2014.05.005

41. E. Hermiati, D. Mangunwidjaja, T. C. Sunarti, O. Suparno, B. Prasetya, Procedia Chemistry, 4, 238(2012), https://doi.org/10.1016/j.proche.2012.06.033

42. D. Mao, X. Zhang, X. Zhang, M. Jia, J. Yao, Chinese Journal of Chemical Engineering, 27, 1067(2019), https://doi.org/10.1016/j.cjche.2018.07.019

43. C. Chen, P. M. Reddy, C. S. Devi, P. Chang, Y. Ho, Enzyme and Microbial Technology, 82, 164(2016), https://doi.org/10.1016/j.enzmictec.2015.10.003

44. H. Fałtynowicz, P. Hodurek, J. Kaczmarczyk, M. Kułażyński, M. Łukaszewicz, Bioorganic Chemistry, 93, 102896(2019), https://doi.org/10.1016/j.bioorg.2019.03.070

45. S. Suganuma, K. Nakajima, M. Kitano, D. Yamaguchi, H. Kato, S. Hayashi, M. Hara, Journal of the American Chemical Society, 130, 12787(2008), https://doi.org/10.1021/ja803983h

46. E. Hermiati, J. Azuma, S. Tsubaki, D. Mangunwidjaja, T. C. Sunarti, O. Suparno, B. Prasetya, Carbohydrate Polymers, 87, 939(2012), https://doi.org/10.1016/j.carbpol.2011.08.033

47. W. Yan, L. Zhang, S. M. Wijaya, Y. Zhou, Bioresource Technology, 296, 122366(2020), https://doi.org/10.1016/j.biortech.2019.122366

48. D. Bhuyan, Rasayan Journal of Chemistry, 14(2), 887(2020), http://doi.org/10.31788/RJC.2021.1426216

[RJC-6276/2020] 